\title{
The Use Of The Four Square Writing Method In Improving Students' Writing Ability Through Narrative Writing In Medan Mulia Elementary School
}

\author{
Dewi Dharma Hardi \\ \{dewidharmahardi@yahoo.com\} \\ Sekolah Tinggi Teologi Pelita Kebenaran ${ }^{1}$
}

\begin{abstract}
This research used a descriptive qualitative method and in a single case study aimed at analyzing students used the four square writing method in developing narrative writing. It also sought to identify the writing aspects that can be improved by using this method. For the sample of this research, thirty nine grade five students were chosen because they had learned quite a lot of English vocabulary which would enable them to write in paragraphs. The instruments for data gathering were the students' writing, observation and questionnaire. The intervention was limited to three sessions of the four square writing. The analysis of the students' writing showed quite good results. The four square writing method was well-received by the students who could follow its structured approach. The study helped identify prewriting strategies that the students need to develop. This research showed the types of writing skills that if present could be more likely to lead to writing success.
\end{abstract}

Key words: four square writing method, narrative writing

\section{Introduction}

According to Alwasilah (2004, p.99) among the four language skills (listening, reading, speaking, and writing), writing has been considered the most neglected one in Indonesian schools. There are several possible reasons why this thing has happened. First, in Indonesian culture, literacy is traditionally defined as "ability to read" rather than "the ability to read and write." Second, the teaching of writing focuses more on theories than skills in writing. It has been reported that the so- called "composition classes" in high schools are dominated by teachers' explanation about grammar (Alwasilah, 2004, p.99). The focus is on sentence and paragraph structures, thus leaving the impression that writing is about applying rules rather than communicating ideas.

Based on the findings above, the researcher is interested in investigating writing. Mason and Washington (as cited in Rozimela, 2004, p. 84) state that the relation of writing to aspects of language is reflected in the process of writing. Therefore, it is important to look at that process. In the process of exploring ideas students may read books and articles, or talk to friends through which they actually practise their reading, listening, and speaking skills. Writing often encompasses the results of reading and conversation.

The researcher realized that writing should be taught from primary school because students require writing skills and need to know how to produce good writing in all levels of 
education. One writing method that the researcher would like to investigate is the four square writing method for improving students' writing ability through writing narrative composition. She is interested in the four square writing method because students are taught to organize their thoughts into topics and subtopics so that they can produce a focused, well-supported and organized composition. The four square method uses a graphic organizer in which students write a general idea, supporting details, and a wrap-up sentence before they write the composition in paragraphs. Teaching writing through the use of a graphic organizer empowers students to write with confidence (Gould and Gould, 1999, p.4). According to Gloria Houston (as cited in Gould and Gould, 1999, p.4) visual organizers help students to conceptualize, understand, and structure a piece of written discourse successfully.

The researcher dselected narrative writing because students felt free to retell familiar stories or wrote about events in their own lives. Students had the opportunity to explore their ideas so that they could enjoy writing their compositions.

\section{Research Method}

This research used descriptive qualitative methods and was designed to provide suggestions for improving the teaching of writing. The researcher first used an inductive process by which she described the specific steps taken in using the four square writing method in narrative writing. After that she analyzed the students' writing and defined the writing aspects that should be improved by the students.

\section{Result and Discussion}

The four square method is a graphic organizer where students plan and organize prewriting and drafting before writing in paragraphs. According to the researcher this writing method adapts the process approach and by using this method students are encouraged to enjoy the process of writing. We can see the four square diagram below:

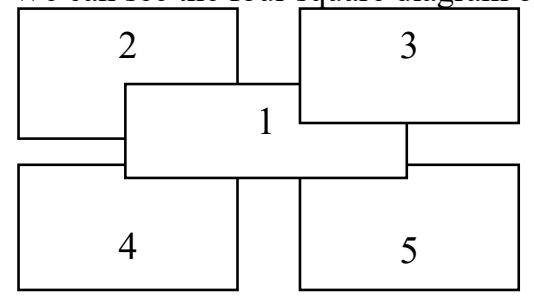

Fig.1. The diagram of the four square

The main, broad or general idea is placed in the center box of the square (box 1). Boxes 2,3 , and 4 are used for supporting ideas. The remaining box, lower right (box 5), will be employed to build a summary or concluding sentence. In practise, this is referred to as the "wrap-up" sentence because it encompasses all the ideas developed in the four squares in the form of a series sentence. Example (taken from Gould and Gould, 1999, p.16): 


\section{My favourite meal is spaghetti and meatballs.}

\begin{tabular}{|c|}
\hline Easy to cook \\
\hline Delicious \\
\begin{tabular}{|l|}
\hline \multicolumn{1}{|c|}{ Fun to eat } \\
My favourite meals are \\
spaghetti and meatballs \\
because they are easy to \\
cook, fun to eat, and \\
delicious.
\end{tabular} \\
\hline
\end{tabular}

Fig. 2. The example of the four square writing

Then, we need to add three supporting details to the supporting ideas. After that, connecting words are added in order to bridge the gap between ideas. These connecting words also provide smooth reading when changing paragraphs. Examples of connecting words are: one reason, first, to begin with, second, another reason, in addition, last, in conclusion, or 'so you can see'. The last step is to incorporate vivid language into writing. Writing with vivid language is achieved by careful, specific word choice. Sensory experiences are an excellent means of providing for vivid expression of thought. Vivid language in writing lets us know what the writer sees, hears, feels, smells and tastes. Vivid language is also heavily involved with the emotional state of the writer (Gould and Gould, 1999, p. 34). After we have finished working in the graphic organizer, it is time to take the writing off the organizer and write it in paragraphs. The four square method has built in a good self-checking mechanism for sentence building. Since each of boxes 2, 3, and 4 had the three items in them, students are reminded to check for four capital letters and four periods in each of the corresponding paragraphs (Gould and Gould, 1999, p. 42). The researcher gave the students writing topics about their families, school subjects, and their favourite food. The main instrument used in the research was the students' writing. Besides that, the researcher observed students during the writing activities and asked the students to fill out a questionnaire. The researcher wrote down what she heard, saw, experienced, and thought in the course of collecting and reflecting on the data (Fraenkel and Wallen, 2006, p. 516). The other instrument was a checklist to record improvement in the students' writing. The students were asked to fill out questionnaires about their writing after they used the four square writing method. There were 39 students who filled out the questionnaires.

$\backslash$ Table 1. The questionnaire

\begin{tabular}{lllcccc}
\hline & \multicolumn{2}{c}{ Statement } & \multicolumn{2}{c}{ Yes } & \multicolumn{2}{c}{ No } \\
No. & \multicolumn{2}{c}{$\begin{array}{c}\text { Number of } \\
\text { students }\end{array}$} & Percentage & $\begin{array}{c}\text { Number of } \\
\text { students }\end{array}$ & Percentage \\
\hline $1 . \quad \begin{array}{l}\text { I like using the four square } \\
\text { writing method. }\end{array}$ & 23 & $59 \%$ & 16 & $41 \%$ \\
\hline
\end{tabular}




\begin{tabular}{|c|c|c|c|c|c|}
\hline \multirow[b]{2}{*}{ No. } & \multirow[b]{2}{*}{ Statement } & \multicolumn{2}{|c|}{ Yes } & \multicolumn{2}{|c|}{ No } \\
\hline & & $\begin{array}{l}\text { Number of } \\
\text { students }\end{array}$ & Percentage & $\begin{array}{l}\text { Number of } \\
\text { students }\end{array}$ & Percentage \\
\hline 2. & $\begin{array}{l}\text { By using the four square writing } \\
\text { method I practise to arrange my } \\
\text { ideas into main ideas. }\end{array}$ & 27 & $69 \%$ & 12 & $31 \%$ \\
\hline 3. & $\begin{array}{l}\text { By using the four square writing } \\
\text { method I practise to add } \\
\text { supporting details to the main } \\
\text { ideas. }\end{array}$ & 29 & $74 \%$ & 10 & $26 \%$ \\
\hline 4. & $\begin{array}{l}\text { By using the four square writing } \\
\text { method I practise to write in } \\
\text { paragraphs. }\end{array}$ & 30 & $77 \%$ & 9 & $23 \%$ \\
\hline 5. & $\begin{array}{l}\text { By using the four square writing } \\
\text { method I can write five } \\
\text { paragraphs. }\end{array}$ & 23 & $59 \%$ & 16 & $41 \%$ \\
\hline 6. & $\begin{array}{l}\text { I use capital letters while I am } \\
\text { writing by using the four square } \\
\text { writing method. }\end{array}$ & 24 & $62 \%$ & 15 & $38 \%$ \\
\hline 7. & $\begin{array}{l}\text { I use punctuation while I am } \\
\text { writing by using the four square } \\
\text { writing method. }\end{array}$ & 33 & $85 \%$ & 6 & $15 \%$ \\
\hline 8. & $\begin{array}{l}\text { I follow my four squares while I } \\
\text { am writing. }\end{array}$ & 29 & $74 \%$ & 10 & $26 \%$ \\
\hline 9. & $\begin{array}{l}\text { I use connecting words in my } \\
\text { writing. }\end{array}$ & 24 & $62 \%$ & 15 & $38 \%$ \\
\hline 10. & $\begin{array}{l}\text { My writing becomes more } \\
\text { organized by using the four } \\
\text { square writing method }\end{array}$ & 32 & $82 \%$ & 7 & $18 \%$ \\
\hline 11. & $\begin{array}{l}\text { The four square writing method } \\
\text { helps me to write better. }\end{array}$ & 33 & $85 \%$ & 6 & $15 \%$ \\
\hline
\end{tabular}

After teaching the students to use the four square writing method in writing narrative writing three times, the researcher found that the students were better able to write in paragraphs and use connecting words in their writing. They were able to write a narrative composition and they enjoyed the writing process.

\section{Conclusion}

The conclusions of this research are:

- The use of the four square writing method can help students to improve their writing ability.

- $\quad$ By using the four square writing method students go through a prewriting and drafting process.

- $\quad$ English teachers need to equip their students with the ablity to write compositions. 


\section{References}

[1] Alwasilah, A.C. Improving writing skills through collaborative writing. In B.Y. Cahyono \& U. Widiati (Eds.), The tapestry of English language teaching and learning in Indonesia (pp. 99109). Malang: State University of Malang Press. 2004.

[2] Berk, L.E. Infants, children, and adolescents (5 $5^{\text {th }}$ ed). Boston, MA: Pearson. 2005.

[3] Fraenkel, J.R., \& N.E. Wallen. How to design and evaluate research in education (6 ${ }^{\text {th }}$ ed.). New York: The McGraw-Hill Companies. 2006.

[4] Gebhard, J.G. Teaching English as a foreign of second language. United States of America: The University of Michigan Press. 1996.

[5] Gould, J.S., \& Gould E.J. Four square writing method for grades 4-6. United States of America: Teaching \& Learning Company. 1999.

[6] Hobelman, P. \& Wiriyachitra A. A balanced approach to the teaching of intermediate-level writing skills to EFL students. The English Teaching Forum 1989-1993 : Creative Classroom Activities (p.122). Washington: English language program division. 1995.

[7] Lorch, S. Basic writing: A practical approach ( $2^{\text {nd }}$ ed.). Boston: Little, Brown and Company. 1984.

[8] Ploeger, K. Simplified paragraph skills. Illinois: NTC Publishing Group. 2000.

[9] Rice, M.K. \& J.U. Burns. Thinking/writing: An introduction to the writing process for students of English as a second language. New Jersey: Prentice Hall Regents. 1986.

[10] Rozimela, Y. The value of writing skills in the senior high school in Indonesia. In B.Y. Cahyono \& U. Widiati (Eds.), The tapestry of English language teaching and learning in Indonesia (pp. 83-98). Malang: State University of Malang Press. 2004. 